\title{
A SYSTEMATIC REVIEW OF THE DUE DILIGENCE STAGE OF MERGERS AND ACQUISITIONS: TOWARDS A CONCEPTUAL FRAMEWORK
}

\author{
V. Bhagwan ${ }^{1 *}$, S.S. Grobbelaar ${ }^{1,2}$ \& W.G. Bam ${ }^{1}$
}

\section{ARTICLE INFO}

\begin{tabular}{|c|c|c|}
\hline \multicolumn{3}{|c|}{$\begin{array}{l}\text { Article details } \\
\text { Presented at the } 29^{\text {th }} \text { annual conference } \\
\text { of the Southern African Institute for } \\
\text { Industrial Engineering (SAIIE), held from } \\
24-26 \text { October } 2018 \text { in Stellenbosch, } \\
\text { South Africa }\end{array}$} \\
\hline \multicolumn{3}{|c|}{ Available online $\quad 9$ Nov 2018} \\
\hline & $\begin{array}{l}\text { Contact details } \\
* \quad 17539242 @ s\end{array}$ \\
\hline \multicolumn{3}{|c|}{ Author affiliations } \\
\hline & $\begin{array}{l}\text { Department } \\
\text { Engineering } \\
\text { University, }\end{array}$ & $\begin{array}{l}\text { ial } \\
\text { sch } \\
\text { a }\end{array}$ \\
\hline & $\begin{array}{l}\text { DST-NRF Ce } \\
\text { Scientometr } \\
\text { Technology } \\
\text { (SciSTIP), St } \\
\text { Africa }\end{array}$ & $\begin{array}{l}\text { cellence in } \\
\text { ience, } \\
\text { ation Policy } \\
\text {, South }\end{array}$ \\
\hline
\end{tabular}

DOI

http://dx.doi.org/10.7166/29-3-2061
ABSTRACT

Organisations are under constant pressure to grow in the face of increased competition, changing conditions, and increasingly relaxed country and currency regulatory environments. In order to remain a player or an idustry leader, it's imperative for companies to achieve real growth. Mergers and acquisitions (M\&A) are an external mechanism for organisations to achieve growth. There are different stages in the typical M\&A transaction. The due diligence stage of a transaction is critical in evaluating whether to proceed with a deal. It provides essential information that is used in setting negotiating parameters, determining bid prices, and providing a basis for integration recommendations. The due diligence process, therefore, should be managed effectively to ensure a higher probability of success for the deal. A systematic literature review was undertaken to establish the key concepts behind due diligence. Due diligence is multidisciplinary in nature, thus a wide range of literature was reviewed to gain a holistic understanding of the process. Concepts identified during the review were then individually examined. Similar concepts were grouped together into a new concept. The outcome of this paper forms the basis of a conceptual framework that captures the key areas of due diligence, the due diligence process and principles.

\section{OPSOMMING}

Organisasies is deurlopend onder druk om te groei in die aangesig van verhoogde mededinging, veranderende omstandighede en toenemend verslapte land- en valuta-regulerende omgewings. Om hul status as 'n rolspeler of industrieleier te handhaaf, is dit van kern belang vir organisasies om ware groei te behaal. Samesmeltings en verwerwings is ' $n$ eksterne meganisme vir organisasies om groei te behaal. Daar is verskillende stadiums in só 'n transaksie. Die noulettendheidsondersoek stadium van ' $n$ transaksie speel ' $n$ kritiese rol in die voortgaanbesluitneming van 'n ooreenkoms. Dit verskaf essensiële inligting wat gebruik word om onderhandelingspunte te stel, die vasstel van 'n aanbod en die daarstelling van integrasie aanbevelings. Hierdie proses moet dus doeltreffend bestuur word om 'n hoër waarskynlikheid van onderhandelingsukses te verseker. 'n Stelselmatige literatuurstudie is onderneem om die sleutelkonsepte te formuleer. 'n Noulettendheidsondersoek is multidissiplinêr van aard en dus beslaan die literatuurstudie ' $n$ noemenswaardige reikwydte om sodoende ' $n$ holistiese verstaan van die proses te bekom. Konsepte wat tydens die literatuurstudie identifiseer is, is saam gegroepeer om nuwe konsepte te vorm. Die resultaat is 'n konseptuele raamwerk wat die sleutel areas van 'n noulettendheidsondersoek saamvat. 
Organisations are under constant pressure to grow in the face of increased competition, changing conditions, shrinking gerographical boundaries, and increasingly relaxed country and currency regulatory environments. In order to remain a player or an industry leader, it is imperative for companies to achieve real growth [1], [2]. Traditional methods of achieving organic growth, such as new products, markets, and efficiencies may only assist in growing the organisation to a certain extent.

Mergers and acquisitions (henceforth referred to as 'M\&A') are an external mechanism for organisations to achieve real growth. M\&A has indeed been a popular growth strategy since the latter part of the twentieth century for both big and small firms [3]. Organisations see M\&A as an alternative strategy for expansion and growth [4]. This is indicated through the increasing value of M\&A deals year on year. For example, acquisitions that were completed in 1997 were valued at more than all the acquisitions that occurred throughout the 1980s [5].

Organisations see M\&A as a valuable tool with which they can increase revenue streams relatively quickly. The outcome of a merger or acquisition can often create new organisations whose financial and strategic options are more promising.

Although M\&A activity is on the rise, the results of many of these deals are dismal [6]. Gomes et al. [7] confirm that less than half of all corporate combinations achieve their financial or strategic objectives. They suggest that the field of M\&A suffers from a lack of connectedness, which leads to the high failure rate in transactions, and that the different streams of M\&A research are only marginally informed by each other. This leads to much of the understanding of M\&A and its complexities being restricted and compartmentalised [7]. Thus there is a need to establish a link between different approaches to M\&A.

Much of the literature points to an M\&A transaction being viewed as a process. Historically, organisations that did not approach the transaction as a process have often been exposed to more risk within the transaction and a higher likelihood of failure.

There are common elements that make up every deal including strategy development, systematic selection and screening of possible targets, due diligence, negotiations, and integration. Many models that describe the M\&A process focus their steps on these core activities. The deal flow model [8] is used in this paper to refer to the various stages of the M\&A process. The stages of this model are summarised in Table 1.

\section{Table 1: The deal flow model [8]}

\section{STAGE DESCRIPTION}

The first stage sets the tone for the rest of the deal; it is therefore important to start off on the correct path. The firm should set out its business objectives and growth strategy in a well-defined, rational, and data-oriented way. The executives should explain what a feasible target would encompass in meeting specific criteria that are grounded in the objectives set out. Criteria can include the likes of market share, geographical access, new products or technologies, and synergies. The executives should decide on the rationale behind the merger or acquisition.

1. Formulate During this stage, the firm searches for desirable target companies. Financial and operational analyses initiate conversations between the executive staff. These conversations lead to high-level identification of potential synergies by the M\&A deal team. The result of this exercise is the letter of intent that contains the initial deal parameters, terms, and conditions.

The third stage of the model consists of a thorough due diligence to explore all aspects of the target company. The due diligence that is conducted should uncover as much detail as possible about the target before finalising a definitive agreement.

3. Investigate/Due Diligence Due diligence should be conducted over several areas, such as finance, operations, legal, and environmental, to name a few. The due diligence team summarises their key findings from the process, and identifies potential deal killers or synergies. The acquiring company uses findings from the due diligence process to set negotiating parameters, determine bid prices, and provide the foundation for initial integration recommendations. 


\begin{tabular}{|c|c|}
\hline STAGE & DESCRIPTION \\
\hline Negotiate & $\begin{array}{l}\text { This stage is made up of process steps and requirements to conclude a deal } \\
\text { successfully. The deal team drives this stage of the transaction. After being briefed } \\
\text { by the due diligence team, the deal team and the senior executives devise the final } \\
\text { negotiating strategy for all terms and conditions of the deal. Considerations for the } \\
\text { final negotiating strategy include factors such as price, performance, people, legal } \\
\text { protection, and governance. }\end{array}$ \\
\hline Integrate & $\begin{array}{l}\text { This stage of the deal should be customised for each company and modified for } \\
\text { each specific deal. This stage involves the process of planning and implementing } \\
\text { the newly merged organisation's processes, people, technology, and systems. } \\
\text { Questions that should be considered to help resolve the host of issues encountered } \\
\text { during this stage include: how fast to integrate; how much disruption will be } \\
\text { created and how the disruption can be minimised; how people can be assisted to } \\
\text { continue focusing on customers, safety, and daily operations; and how best to } \\
\text { communicate with all stakeholders. }\end{array}$ \\
\hline 6. Motivate & $\begin{array}{l}\text { The final stage of this model is focused on maximising the long-term value of the } \\
\text { merger's firm. When major integration activities have been completed and most, if } \\
\text { not all, projected synergies have been realised, management's responsibility moves } \\
\text { to the demands of driving the organisation forwards to achieve continuous } \\
\text { performance improvements. }\end{array}$ \\
\hline
\end{tabular}

The literature points to Stage 3, investigate/due diligence, as critical in evaluating whether an organisation should proceed with the M\&A deal. Outcomes from the due diligence stage are used to set negotiating parameters, determine bid prices, and provide a basis for initial integration recommendations [9]. Furthermore, the due diligence stage plays an important role in determining whether a deal will be successful. According to Perry and Herd [10], the danger is not that an organisation will fail to complete the due diligence for a deal, but rather that they will fail to complete the due diligence effectively.

A gap exists in the research into the processes that should be followed for the due diligence stage of a transaction. Currently there is no guideline or model to direct an organisation about which due diligence investigations to apply to an M\&A transaction, and what priority should be assigned to the various due diligence investigations to facilitate a decision on how to proceed with the transaction. It is also unclear what level of investigation is required within a transaction to minimise the risks involved and to ensure a successful transaction. Finally, the literature identifies a deficiency in the knowledge of the different outcomes that the due diligence investigations could lead to, and how this impacts the overall transaction and the steps that could be taken to deal with these outcomes.

This paper presents the findings of a systematic literature review for the due diligence stage of an M\&A transaction. The review is guided by the following research questions:

1. What are the various areas of due diligence investigations?

2. What are the tools/data/processes that are required to conduct these due diligence investigations?

3. What are the key concepts of the due diligence process?

4. What are the best practice and strategies for the due diligence process?

\section{METHODOLOGY}

In order to develop a conceptual framework, Jabareen's [11] conceptual framework analysis (CFA) method is adopted for this study. CFA is a grounded theory technique that aims to generate, identify, and trace the concepts of the subject under investigation. This procedure is flexible and allows for modification to assist in completely understanding the phenomena surrounding the subject. The process of the systematic literature review, and the analysis of the results, are outlined in this paper. The steps towards an initial conceptual framework are also discussed.

The CFA method is broken up into eight phases. The phases to be covered in this paper are phases 1 to 5 ; the remaining three phases will be covered in future work. Table 2 provides a breakdown of these phases and the corresponding sections in this paper where they are covered. 
Table 2: Research methodology towards the development of a conceptual framework (adapted from Jabareen [11])

\begin{tabular}{|c|c|c|c|}
\hline CFA PHASE & OBJECTIVE OF PHASE & ACTION COMPLETED & SECTION \\
\hline $\begin{array}{l}\text { Phase 1: Mapping } \\
\text { the selected data } \\
\text { sources }\end{array}$ & $\begin{array}{l}\text { - } \quad \text { Identify gap in literature. } \\
\text { - } \quad \text { determine research } \\
\text { questions. } \\
\text { - } \quad \text { Identify sources of data. } \\
\text { - } \quad \text { Define search terms. } \\
\text { Decide on a filtering } \\
\text { - } \quad \text { Select studies. }\end{array}$ & $\begin{array}{l}\text { Preparation and initiation of } \\
\text { systematic literature review. }\end{array}$ & $\begin{array}{l}\text { 3.1.1. } \\
3.1 .2\end{array}$ \\
\hline $\begin{array}{l}\text { Phase 2: Extensive } \\
\text { reading and } \\
\text { categorising of the } \\
\text { selected data }\end{array}$ & $\begin{array}{l}\text { - } \text { Read through the selected } \\
\text { studies to gain a better } \\
\text { understanding. } \\
\text { - } \quad \text { Identify data categories. } \\
\text { - Organise data according to } \\
\text { categories. }\end{array}$ & $\begin{array}{l}\text { Data categories established. } \\
\text { Data extracted from papers and } \\
\text { coded in Microsoft Excel. }\end{array}$ & 3.1.3. \\
\hline $\begin{array}{l}\text { Phase 3: Identifying } \\
\text { and naming concepts }\end{array}$ & $\begin{array}{l}\text { - Identify concepts through } \\
\text { extensive reading. } \\
\text { - Identify core concepts, } \\
\text { principles, and processes. }\end{array}$ & $\begin{array}{l}\text { Concepts are identified and } \\
\text { named. } \\
\text { Completion of systematic } \\
\text { literature review. }\end{array}$ & 5.2 . \\
\hline $\begin{array}{l}\text { Phase 4: } \\
\text { Deconstructing and } \\
\text { categorising the } \\
\text { concepts }\end{array}$ & $\begin{array}{l}\text { Deconstruct each concept } \\
\text { according to its main } \\
\text { attributes, characteristics, } \\
\text { assumptions, and role. } \\
\text { Organise and categorise } \\
\text { concepts according to their } \\
\text { features. }\end{array}$ & $\begin{array}{l}\text { Core concepts emerge and are } \\
\text { critically analysed. } \\
\text { Concepts are organised into } \\
\text { specific categories. }\end{array}$ & 5.3. \\
\hline $\begin{array}{l}\text { Phase 5: Integrating } \\
\text { concepts }\end{array}$ & $\begin{array}{l}\text { Group together or integrate } \\
\text { concepts that have } \\
\text { similarities to form new } \\
\text { concepts. }\end{array}$ & $\begin{array}{l}\text { Three areas are identified in } \\
\text { which concepts are categorised, } \\
\text { forming the basis of the } \\
\text { conceptual framework. }\end{array}$ & 6. \\
\hline
\end{tabular}

\section{SYSTEMATIC LITERATURE REVIEW}

Systematic literature reviews are carried out in research to answer predetermined questions. Empirical evidence is identified from all applicable studies that fit the predefined criteria, and is then analysed and integrated [12]. Systematic literature reviews are a method for mapping out uncertainty and identifying where gaps in literature exist, thus highlighting any opportunities for future work [13].

\subsection{Phase 1: Mapping the selected data sources}

\subsubsection{Data collection}

Phase 1 of the CFA method, discussed in Table 2, shows that the first step is searching for and selecting the relevant literature works. Data was acquired using the web-based search engines Google Scholar and Scopus. The primary search terms used included 'M\&A' and 'due diligence'. The search term 'M\&A' was also interchanged with the term 'mergers and acquisitions' to increase the effectiveness of the search. Secondary search terms that were employed in the data collection process included 'methodology', 'framework', 'process', 'tools', 'data', 'outcomes', and 'costs'. These secondary search terms were used in various combinations; however, it was found that the results remained relatively consistent, with only minor changes recorded. The initial results from these searches are shown in Table 3. More than 1000 publications were identified in this initial search. 
Table 3: Initial search results

\begin{tabular}{|c|c|c|}
\hline SEARCH TERMS & SCOPUS & GOOGLE SCHOLAR \\
\hline $\begin{array}{l}\text { ('Mergers and Acquisitions') OR ('M\&A') AND ('Due } \\
\text { Diligence') }\end{array}$ & 181 & 24400 \\
\hline $\begin{array}{l}\text { ('Mergers and Acquisitions') AND ('Due Diligence') AND } \\
\text { ('Methodology' OR 'Framework' OR ‘Process') }\end{array}$ & 90 & 15700 \\
\hline $\begin{array}{l}\text { ('Mergers and Acquisitions') AND ('Due Diligence') AND } \\
\text { ('Tools' OR 'Data' OR 'Processes') }\end{array}$ & 89 & 15100 \\
\hline $\begin{array}{l}\text { ('Mergers and Acquisitions') AND ('Due Diligence') AND } \\
\text { ('Outcomes') }\end{array}$ & 70 & 6160 \\
\hline $\begin{array}{l}\text { ('Mergers and Acquisitions') AND ('Due Diligence') AND } \\
\text { ('Costs') }\end{array}$ & 30 & 12600 \\
\hline
\end{tabular}

\subsubsection{Data selection}

The data selection process was used to reduce and filter the number of publications. From this process, a comprehensive literature database was established as the basis of the systematic literature review. The data selection process that was followed is illustrated in Figure 1.

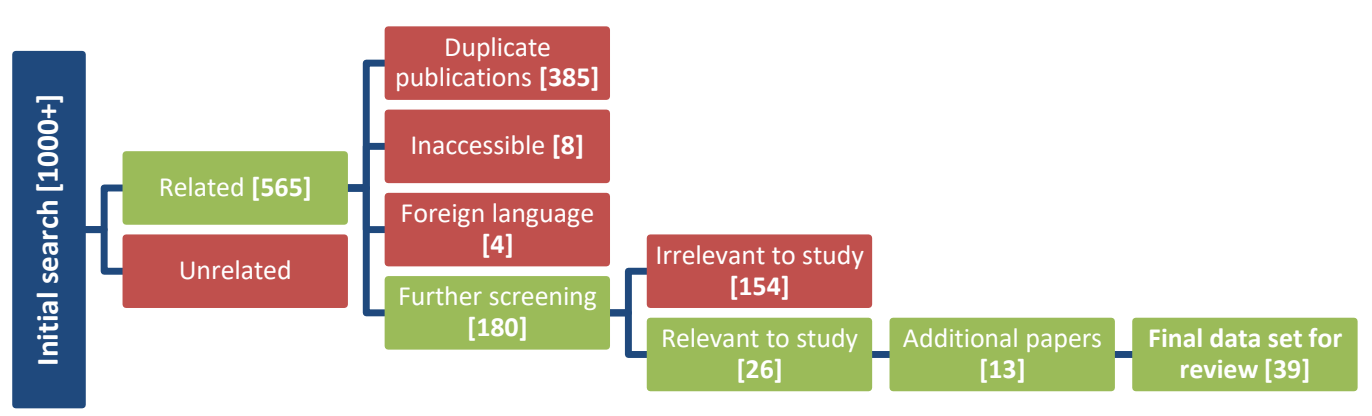

Figure 1: Data selection process

The number of duplicate publications removed was 385. A further four publications were removed on the basis of their being in a foreign language. Another eight publications were removed as they were inaccessible. A screening process of the remaining 180 articles was then carried out.

Using the title and abstract of the papers, a screening process was used to filter the publications. Two factors were used to assist in determining whether the publication under examination would be accepted for review. These factors are shown in Table 4. A score for each factor was allocated to the publication, based on relevance to the factor in question. A score of 0 was allocated if it was irrelevant to the factor, 0.5 if it was partially relevant to the factor, and 1 if it was relevant to the factor.

Table 4: Factors used in the screening process for publications

\begin{tabular}{|c|l|}
\hline FACTOR & DESCRIPTION \\
\hline $\mathbf{1}$ & Addresses due diligence in some significant way \\
\hline $\mathbf{2}$ & $\begin{array}{l}\text { Identifies/examines/proposes concepts/theories/frameworks/models concerning due diligence } \\
\text { within M\&A }\end{array}$ \\
\hline
\end{tabular}

The ancestry approach was employed to add additional papers to the literature database that had been created. This approach involves tracking research cited in the literature that has been obtained already [14]. In total, 13 papers were added to the literature database using this approach.

The final comprehensive literature database consisted of 39 articles for review. A list of these publications is available in Appendix A. 


\subsection{Phase 2: Extensive reading and categorising of the selected data}

To fulfil the requirements of phase 2 of CFA (see Table 2), extensive reading of the data is necessary to gain a better understanding of due diligence, and to establish categories for data collection. The categories with their attributes are presented in Table 5 below.

Microsoft Excel was used to code the selected studies as they were reviewed. Coding of these studies allowed the reviewer to gain an understanding of the underlying concepts of the field of due diligence while also picking up on certain trends from the data being coded. The process of coding involved the allocation of a specific code or category component to a concept or factor identified within the publication under review. Table 5 also displays the corresponding code, where applicable, that is assigned to each category or attribute. The code, along with a number, was assigned to each new concept or factor that was coded.

Table 5: Data collection categories and components/attributes

\begin{tabular}{|c|c|}
\hline CATEGORIES & OMPONENTS / ATTRIBUTES \\
\hline 1. Paper characteristics & $\begin{array}{ll}- & \text { Title of document } \\
- & \text { Author(s) } \\
\text { - } & \text { Year published } \\
- & \text { Document type } \\
- & \text { Document source } \\
- & \text { Citations } \\
- & \text { Geographic focus of document } \\
\text { - } & \text { Industry focus }\end{array}$ \\
\hline 2. Empirical elements & $\begin{array}{ll}\text { - } & \text { Data collection methods } \\
\text { - } & \text { Validation techniques } \\
\text { - } & \text { Gap in literature addressed }\end{array}$ \\
\hline 3. Areas of due diligence & $\begin{array}{ll}- & \text { Financial [FD] } \\
\text { - } & \text { Legal [LD] } \\
\text { - } & \text { Tax [TD] } \\
\text { - } & \text { Environmental [ED] } \\
\text { - } & \text { Regulatory [RD] } \\
\text { - } & \text { Operational [OD] } \\
\text { - } & \text { Market [MAD] } \\
\text { - } & \text { Human resources [HRD] } \\
\text { - } & \text { Cultural [CD] } \\
\text { - } & \text { Strategic [SD] } \\
\text { - } & \text { Marketing [MD] } \\
- & \text { Intellectual property [IPD] } \\
\text { - } & \text { Technology [TD] } \\
\text { - } & \text { R\&D [RDD] } \\
\end{array}$ \\
\hline 4. Due diligence process factors & $\begin{array}{ll}- & \text { Steps [ST] } \\
- & \text { Planning [P] } \\
- & \text { Tools }[\mathrm{T}] \\
- & \text { Success factors }[\mathrm{SF}] \\
- & \text { Risk factors [RF] }\end{array}$ \\
\hline 5. Due diligence concepts and principles & $\begin{array}{ll}- & \text { Best practices [BP] } \\
- & \text { Considerations [CO] } \\
\text { - } & \text { Strategies [S] } \\
\text { - } & \text { Costs [C] } \\
\end{array}$ \\
\hline 6. Observations & $\begin{array}{ll}\text { - } & \text { Conclusions drawn by authors of the paper } \\
\text { - } & \text { Oversights in paper }\end{array}$ \\
\hline
\end{tabular}

The aim of the systematic literature review was to formulate an analysis that emphasised identifying the key areas, processes, principles, and concepts of due diligence. The analysis of the results of the systematic review is presented in Section 4.

\section{$4 \quad$ INTRODUCTION TO DUE DILIGENCE}

Angwin [15] defines due diligence as a comprehensive process of investigating and evaluating business opportunities in mergers and acquisitions. Due diligence usually occurs before major deals are made, or after the deal is announced. Traditional due diligence includes the review and analysis of 'hard data' about the business, and typically covers aspects such as products, financial assets, 
business models, and technology, with most of the focus being placed on legal and financial issues [16].

Due diligence is essentially the process of conducting research on a firm. Its role in M\&A is to support the valuation process, arm the negotiators, test the accuracy of representations and warranties contained in the merger agreement, fulfil disclosure requirements to investors, and inform the planners of post-merger integration [1].

In a report by the Delta Publishing Company [9], key areas are discussed about where to focus the due diligence investigations. The first is the market, where questions - such as the size of the target market, the rate of growth of specific segments, any threats that exist from rival products or technologies, and the extent to which the market is influenced or controlled by the government should be asked.

The second key area is the customers. Investigations are carried out into the target's major customers, their purchase criteria (price, quality, reliability), the various customer channels, any unmet needs, and whether or not a change in buying behaviour is to be expected following completion of the transaction [9].

The third key area is the competitors. Here, the due diligence needs to focus on identifying the target's main competitors, the degree of rivalry between competitors, the strengths and weaknesses of competitors, whether barriers of entry exist for new competitors, and how competitors might try to exploit the merger or integration issues to their own advantage [9].

The final area on which to focus, according to the Delta Publishing Company [9], is culture and human resources. Investigations into which key people must be kept, the core areas of competency that should be retained, and the possibility of doing either, must be conducted. Due diligence should also find out whether there are any major cultural discrepancies with the target, whether they could cause major defections or other losses of productivity, and whether the organisation is willing to resolve them, and at what cost.

Many of the deals that occurred during the 1980s produced disappointing results. Harvey and Lusch [17] suggest that part of the reason for this was the limited due diligence done for these deals. Many of these companies found that the cost of acquisition was not what was paid for the company, but rather, was all that was paid after the company had been purchased to remedy problems not uncovered during the due diligence stage of the transaction [18]. From these findings it is clear that due diligence forms a critical part of the M\&A transaction and can, indeed, influence the success of the deal.

Harvey and Lusch [17] discuss various issues that arise during a transaction that can impede the level of due diligence conducted. The identified issues are characterised as time restrictions, cost constraints, and situational factors. A description of each of these characteristics is given in Table 6.

Due diligence covers a variety of areas. Ideally, a thoroughly conducted due diligence considers all aspects of the target's business. These areas include, but are not limited to, legal, accounting, taxation, information technology, risk and insurance, environment, market presence and sales, operations, real and personal property, intellectual and intangible assets, finance, cross-border issues, organisation and human resources, culture, and ethics [1].

\section{REVIEW ANALYSIS AND RESULTS}

This section highlights the results of the systematic literature review. It begins with an illustration of the descriptive statistics of all the papers reviewed during the process. The remainder of this section addresses phases 3 and 4 of the CFA by providing an introduction to concept identification, followed by the deconstruction and categorisation of these concepts. 
Table 6: Characteristics that impede the level of due diligence conducted [17]

\begin{tabular}{|l|l|}
\hline CHARACTERISTIC & DESCRIPTION \\
\hline Time restrictions & $\begin{array}{l}\text { Time restrictions are highly important and significant in many deals. With this } \\
\text { constraint present, it is highly likely that effective examination of the target, } \\
\text { apart from the major financial, legal, tax, and sales projections, does not } \\
\text { occur. }\end{array}$ \\
\hline Cost constraints & $\begin{array}{l}\text { It is often seen as too costly to bring in experts from every functional area to } \\
\text { provide an opinion. Cost constraints are usually a function of the size of a } \\
\text { deal; if the deal is relatively small, then it is seen as uneconomic to invest a } \\
\text { lot in the due diligence. }\end{array}$ \\
\hline Situational factors & $\begin{array}{l}\text { Situational factors, such as foreign acquisitions and hostile takeovers, have } \\
\text { been the causes of shortcuts taken in due diligence. The competitive nature } \\
\text { of bidding for a company has required less than well-articulated due } \\
\text { diligence. }\end{array}$ \\
\hline
\end{tabular}

\subsection{Descriptive statistics}

In this section, the descriptive statistics of the systematic literature review are presented and discussed. Various bibliometric indicators are presented in order to gain a better understanding of the analysis.

Figure 2 shows the timeline and composition of the papers included in the review. Articles make up the bulk of the papers at 62 per cent, followed by reviews at 23 per cent. The majority of the papers in the review were published after 2001, indicating that information obtained from the papers presents an accurate view of the field of due diligence today.

Figure 3 provides a breakdown of citations for each publication type. It is clear that articles account for the highest number of citations. All citation statistics were obtained from Google Scholar to ensure consistency.

\section{TIMELINE OF PAPERS}

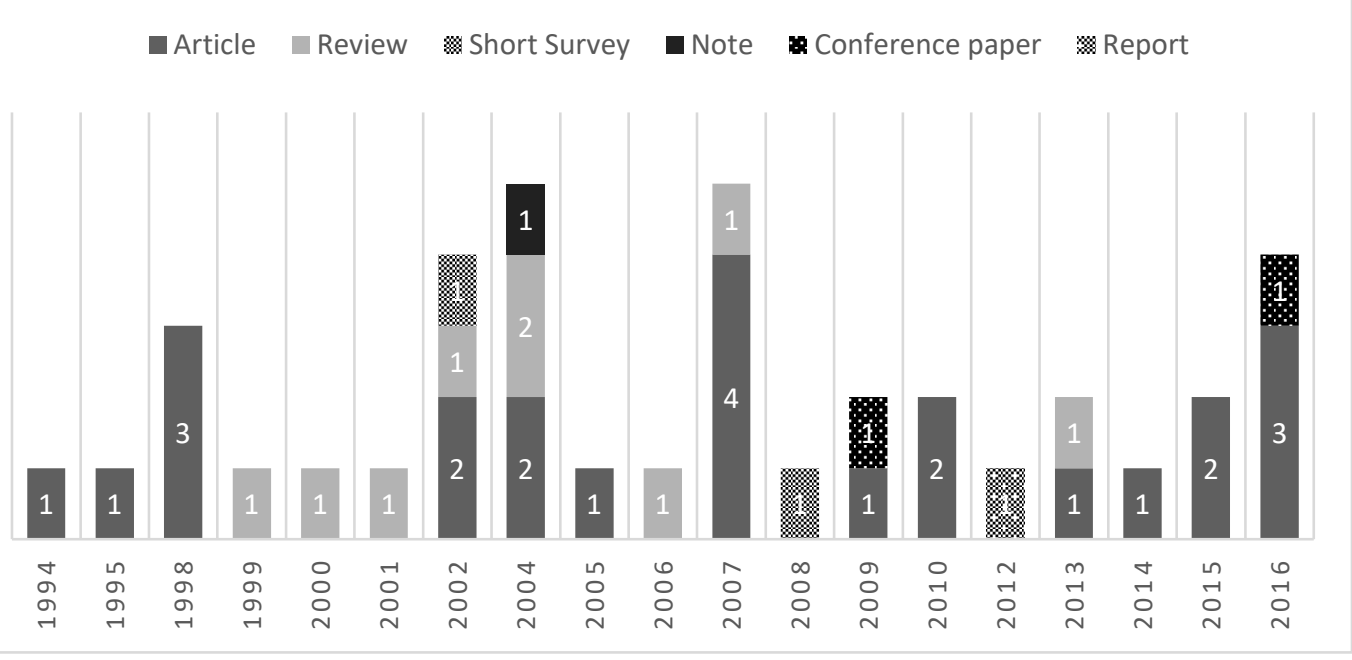

Figure 2: Timeline and type of papers included in the study 


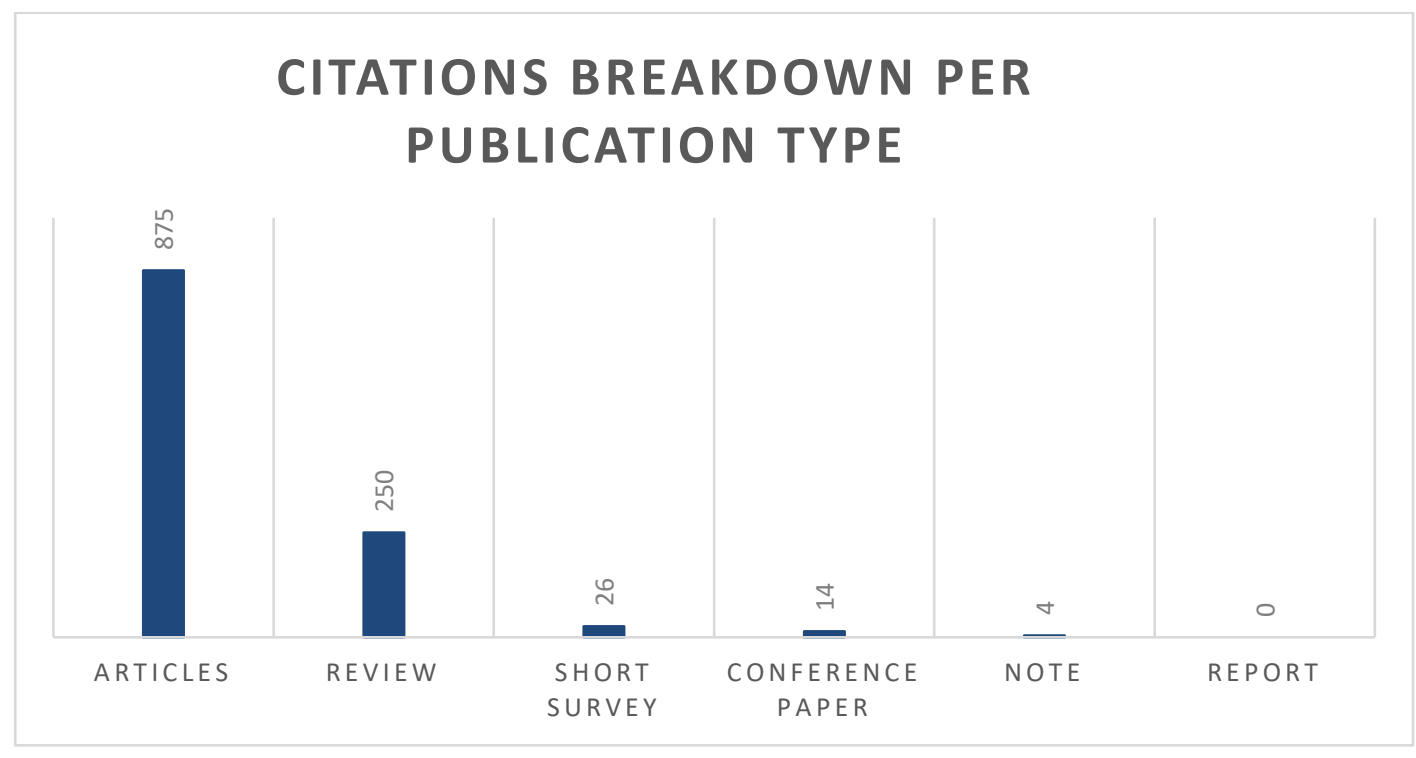

Figure 3: Citations per publication type

\subsection{Phase 3: Identifying and naming concepts}

Following the completion of the review of papers, three important fields were identified:

1) The different areas of due diligence

2) Due diligence process factors

3) Due diligence concepts and principles

Each of these fields will be discussed to aid in the process of concept identification, in accordance with phase 3 of the CFA.

\subsubsection{Areas of due diligence}

There are different areas of focus in the due diligence process. The areas of due diligence have been selected in accordance with standard due diligence practices. Areas that were overlooked were added when mentioned in the papers under review. For example, in the article by Lemieux and Banks [19], several factors in the areas of research and design (R\&D) were mentioned. It was therefore added to the list of areas of due diligence covered by this review. Figure 4 provides a breakdown of the number of factors or concepts identified for each of the different areas of due diligence that were covered in this review.

It is clear from Figure 4 that financial due diligence is heavily weighted in terms of importance due to the number of factors or concepts extracted from the papers reviewed. The other areas of due diligence that seem to be significant are environmental, marketing, cultural, and intellectual property (IP).

It should be noted that areas of due diligence such as legal and tax already have stringent guidelines in place, dictated by the competition legislation of the country or region. They are therefore not covered as comprehensively in the academic literature, which seems to focus more on those areas of due diligence that are often overlooked.

Table 7 provides a description and breakdown of the various areas of due diligence that were covered in the review. 


\section{FACTORS/CONCEPTS IDENTIFIED FOR EACH AREA OF DUE DILIGENCE}

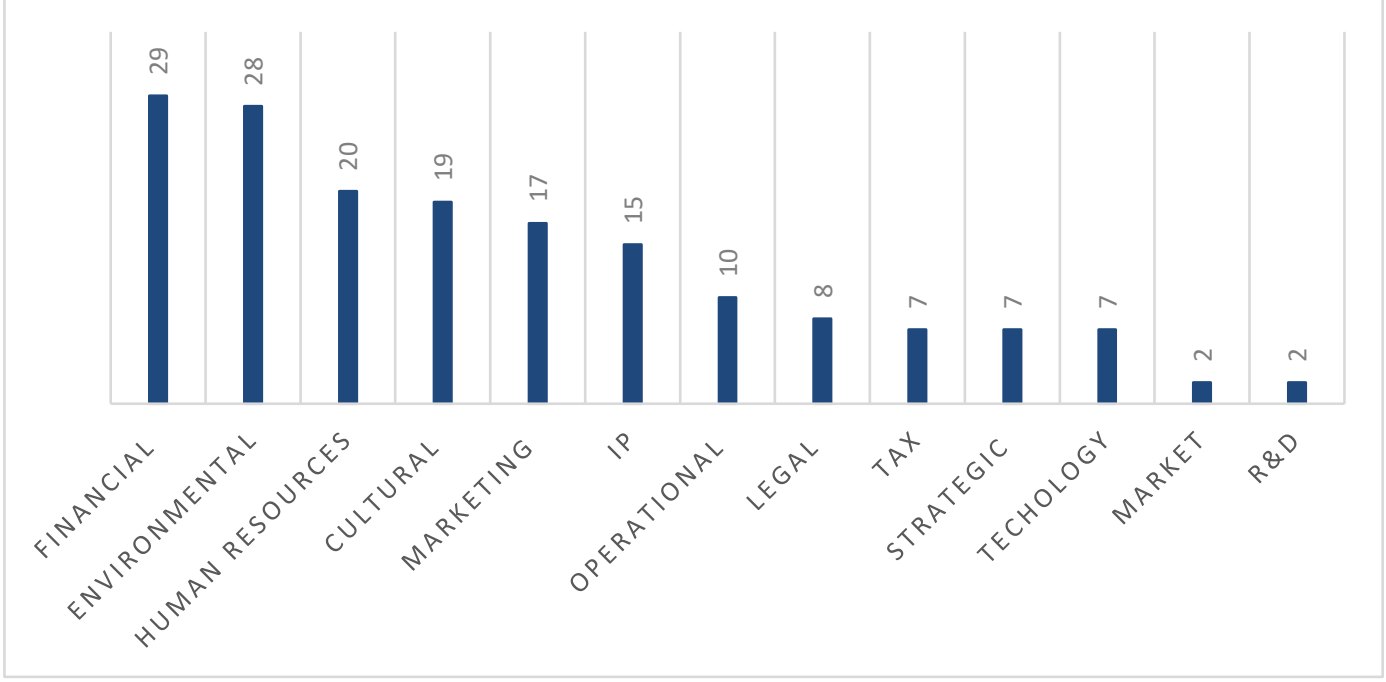

Figure 4: The number of factors/concepts uncovered for each area of due diligence

Table 7: Breakdown of the different areas of due diligence

\begin{tabular}{|c|c|}
\hline $\begin{array}{l}\text { AREA OF DUE } \\
\text { DILIGENCE }\end{array}$ & DESCRIPTION \\
\hline Financial & $\begin{array}{l}\text { It consists of a thorough analysis and assessment of a company's books in order } \\
\text { clearly and reliably to present the company's current financial situation, and make it } \\
\text { easier for the acquirer to understand the character of the company's operation in } \\
\text { financial terms. A buyer must be convinced that the deal makes economic sense, and } \\
\text { must scrutinise historical income statements, balance sheets, and financial forecasts. } \\
\text { Consolidators should look at ways of reducing overhead costs if a deal goes ahead } \\
\text { [20]. }\end{array}$ \\
\hline Legal & $\begin{array}{l}\text { Legal due diligence must assess the condition of the target in four dimensions: (1) } \\
\text { corporate organisation, (2) ownership of assets and exposure to associated liabilities, } \\
\text { (3) actual and potential litigation, and (4) regulation [1]. }\end{array}$ \\
\hline Tax & $\begin{array}{l}\text { Investigations should focus on the target's compliance with tax laws and regulations. } \\
\text { The primary concern of tax due diligence is to determine the buyer's exposure to the } \\
\text { target's possible unpaid taxes and to tax fraud. Investigations should also identify } \\
\text { any opportunities for tax reductions [1]. }\end{array}$ \\
\hline Environmental & $\begin{array}{l}\text { The aim of environmental due diligence is to issue an opinion of compliance with } \\
\text { respect to environmental law, calculate the costs of detected environmental } \\
\text { liabilities, and reduce the risks of legal litigations [21]. The investigations should also } \\
\text { determine the target's compatibility with the buyer's environmental strategy, and } \\
\text { identify any cost improvements in the environmental processes, such as reducing } \\
\text { inefficiencies in the disposal of waste [1]. }\end{array}$ \\
\hline Operational & $\begin{array}{l}\text { Understanding the operations of the target company is important, as it allows the } \\
\text { acquirer to see how they will fit into their enterprise structure. Operational due } \\
\text { diligence is the process by which a potential buyer reviews the operational aspects of } \\
\text { a target company. The approach to operational due diligence varies by industry. The } \\
\text { process itself should be executed by specialists and professionals who understand the } \\
\text { industry and have a background in it [22]. }\end{array}$ \\
\hline Market & $\begin{array}{l}\text { Market due diligence should gain a thorough understanding of the target's market. } \\
\text { The acquirer should also conduct market assessments across the market segments } \\
\text { within which the target operates [23]. Due diligence in this area should also uncover } \\
\text { any opportunities within the market and potential synergies with the acquirer [1]. }\end{array}$ \\
\hline Human resources & $\begin{array}{l}\text { This is an important investigation for any type of transaction or deal. The } \\
\text { investigations should look into the following areas: (1) adequacy of talent and } \\
\text { leadership, (2) exposure to workforce problems such as union issues, (3) } \\
\text { inefficiencies in compensation and benefits, (4) exposure to benefit claims, and (5) } \\
\text { compatibility of organisation and HR policies [1], [24]. }\end{array}$ \\
\hline
\end{tabular}




\begin{tabular}{l}
$\begin{array}{l}\text { AREA OF DUE } \\
\text { DILIGENCE }\end{array}$ \\
\begin{tabular}{ll|} 
Cultural & $\begin{array}{l}\text { Cultural differences between the target and the buyer are believed to contribute to } \\
\text { the high failure rate of M\&A transactions [25]. Due diligence investigations of the } \\
\text { target's culture should aim to assess resemblance on three levels: (1) between } \\
\text { actions and aspirations, (2) between the cultures of buyer and target, and (3) } \\
\text { between the target's culture and its strategic threats and opportunities [1]. }\end{array}$ \\
Strategic & $\begin{array}{l}\text { Strategic due diligence explores whether the potential value and concern about } \\
\text { buying the target at the right price is realistic. It tests the strategic rationale behind } \\
\text { a proposed transaction with two broad questions: Is the deal commercially } \\
\text { attractive? And are we capable of realising the targeted value? [26] }\end{array}$ \\
\hline Marketing & $\begin{array}{l}\text { Marketing due diligence assists in the strategic fit between the target and acquirer. } \\
\text { It employs an analytical methodology that assesses the target's sales and marketing } \\
\text { strengths and weaknesses to ensure that the deal meets the financial, strategic, and } \\
\text { operational objectives of the acquirer [27]. A key aspect of marketing due diligence } \\
\text { is to study the deal through the eyes of the customer; this is critical to market-facing } \\
\text { businesses [28]. }\end{array}$ \\
$\begin{array}{l}\text { Intellectual } \\
\text { property (IP) }\end{array}$ & $\begin{array}{l}\text { IP due diligence should focus on the intellectual and intangible aspects that can be } \\
\text { owned in the legal sense. Patents, copyrights, trademarks, trade secrets, software, } \\
\text { and any other IP of the target should be investigated and analysed. These } \\
\text { investigations should also uncover any infringement claims by others on the target } \\
\text { [1], [29]. }\end{array}$ \\
(Research \& design & $\begin{array}{l}\text { Technology due diligence should focus primarily on IT issues of the target. The } \\
\text { target's compatibility in terms of technology should be assessed in these } \\
\text { investigations. The target's IT department should be evaluated. A plan should also be } \\
\text { drawn up for post-merger integration [1], [30]. }\end{array}$ \\
\hline Rechnology \\
only be carried out on specific targets. The capabilities of the R\&D department of \\
the target are analysed in these investigations. Potential synergies should also be \\
identified [19].
\end{tabular} \\
\hline
\end{tabular}

\subsubsection{Due diligence process factors}

There are many ways in which to approach the due diligence process. The aim of identifying the concepts and factors in the due diligence process is to gain an understanding of the different methods currently in use, and to assist in creating a framework that considers a comprehensive approach to due diligence.

In identifying the various steps and planning factors across the diverse data set of papers, it is possible to explore where there are gaps in the literature on the due diligence process. It is also important to uncover the various tools that are used during the process of due diligence. While some tools are common to the due diligence process, there are some that are not commonly used, and the purpose of identifying the tools in the due diligence process will enable the creation of a comprehensive framework.

Success and risk factors were also examined in the review process, as one of the underlying motivations in this research is to ensure the maximum probability of success. The due diligence process is responsible for uncovering any risks that may occur in the deal, and to assist in mitigating those risks.

Figure 5 indicates the number of factors and concepts extracted from the dataset of papers reviewed. The highest number of concepts or factors extracted were for the steps in the due diligence process, followed by the risk factors. 


\section{Number of factors or concepts extracted for the due diligence process}

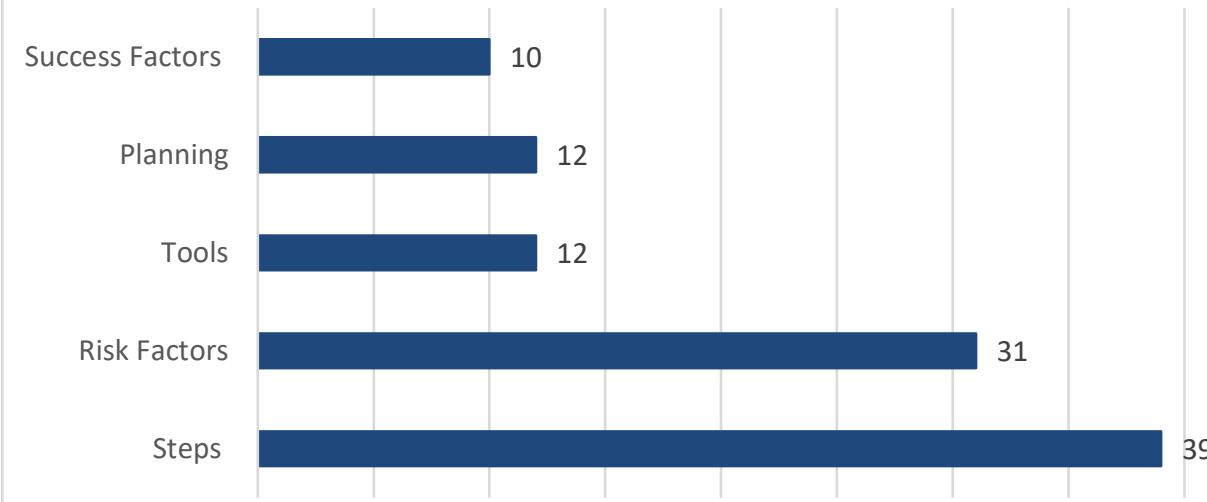

39

Figure 5: The number of factors/concepts extracted from the dataset for the due diligence process

\subsubsection{Due diligence concepts and principles}

Owing to the diverse nature of due diligence, various principles and key concepts were considered when reviewing the dataset of papers. The concepts and principles were extracted according to four categories: best practice, considerations, strategies, and costs. Figure 6 indicates the number of concepts and principles extracted for each of the categories.

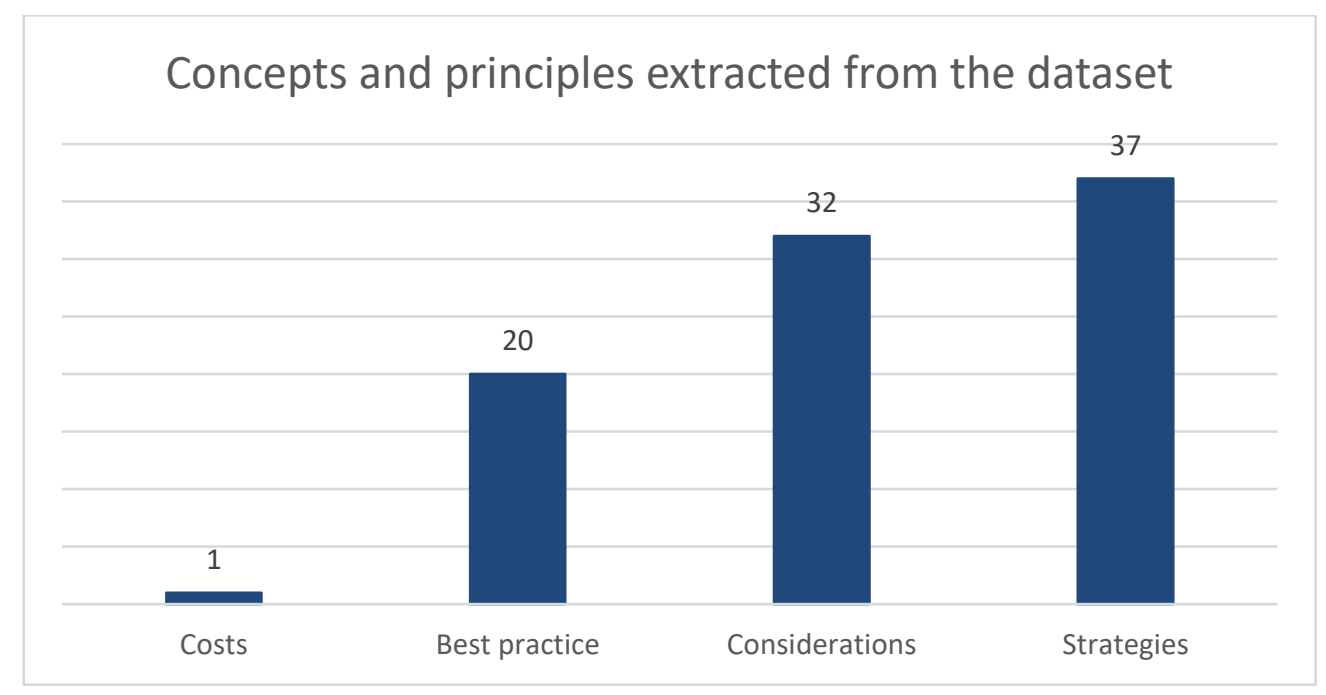

Figure 6: Concepts and principles extracted from the dataset

\subsection{Phase 4: Deconstructing and categorising the concepts}

In this phase, the concepts and factors that were identified in the review were analysed and categorised according to their features and goals. Many of the identified concepts had similarities in their attributes, characteristics, or assumptions, and therefore were combined into one concept. The categories that have been used are carried though from Section 5.2, and include best practice, strategies, success factors, and risk factors. It was found that the concepts, principles, or factors from the considerations category could be allocated to the various other categories, according to their features and goals. 
Table 8 below provides a breakdown of the concepts identified through the review. These concepts have been arranged according to their category.

Table 8: Categorised concepts

\begin{tabular}{|c|c|c|c|}
\hline CATEGORY & CONCEPT & DESCRIPTION & REFERENCES \\
\hline \multirow{5}{*}{ 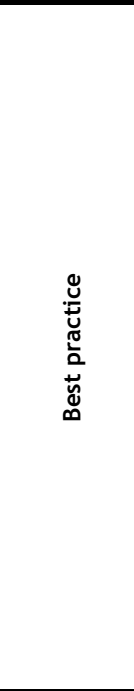 } & Merger teams & $\begin{array}{l}\text { It is important to have a dedicated merger team composed of a range of } \\
\text { operational experts (both internal and external). The inclusion of line } \\
\text { management in the search-and-selection builds understanding of, and } \\
\text { buy-in to, the acquisition strategy among the people who will be running } \\
\text { the acquired business. }\end{array}$ & $\begin{array}{l}{[22]} \\
{[10]} \\
{[26]} \\
{[6]}\end{array}$ \\
\hline & $\begin{array}{l}\text { Checklist for } \\
\text { due diligence }\end{array}$ & $\begin{array}{l}\text { Checklists should be living documents that are modified as regulations } \\
\text { or issues become more complex. Review the checklist to assure that } \\
\text { new issues haven't arisen that should be considered. Checklists ensure } \\
\text { that all investigations have been carried out as they should be. }\end{array}$ & [31] \\
\hline & $\begin{array}{l}\text { A vision for the } \\
\text { combined } \\
\text { organisation }\end{array}$ & $\begin{array}{l}\text { It is crucial that an acquirer has a strong and clear sense of purpose. } \\
\text { This purpose comes from a guiding vision, a defining mission, and a deep } \\
\text { understanding of the markets served, and the strategies, competencies, } \\
\text { and so on that add granularity and distinctiveness to the vision and } \\
\text { mission. }\end{array}$ & [6] \\
\hline & Trust, but verify & $\begin{array}{l}\text { Sellers will often make promises that could make the buyer complacent. } \\
\text { It is important not to take these assurances at face-value, but to carry } \\
\text { out a thorough due diligence to ensure that integration can occur as } \\
\text { smoothly as possible. }\end{array}$ & [10] \\
\hline & $\begin{array}{l}\text { Have clarity } \\
\text { about what the } \\
\text { acquirer is } \\
\text { looking for, and } \\
\text { focus on what } \\
\text { matters }\end{array}$ & $\begin{array}{l}\text { Be clear about the criteria you are looking for in the acquisitions and } \\
\text { the metrics by which the deals will be judged. Emphasise the areas that } \\
\text { matter most in this deal. }\end{array}$ & $\begin{array}{l}{[22]} \\
{[10]}\end{array}$ \\
\hline \multirow{8}{*}{ 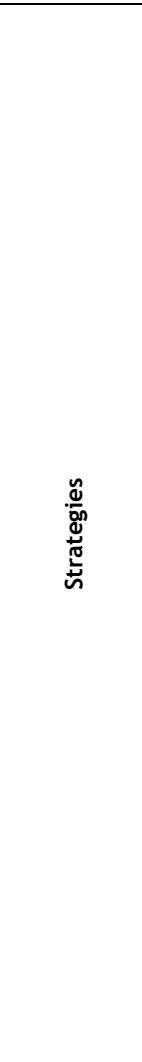 } & M\&A motivation & $\begin{array}{l}\text { Due diligence should identify the primary motivation for considering an } \\
\text { M\&A. The motivation to purchase another company needs to be } \\
\text { understood by the due-diligence team in order for them to focus their } \\
\text { search for candidate firms better. }\end{array}$ & [32] \\
\hline & $\begin{array}{l}\text { Amount and } \\
\text { depth of due } \\
\text { diligence }\end{array}$ & $\begin{array}{l}\text { If insufficient investigation is done, it could mean that something is } \\
\text { missed; on the other hand, too much investigation could mean a rise in } \\
\text { costs and time spent going through the information. }\end{array}$ & $\begin{array}{l}{[33]} \\
{[17]}\end{array}$ \\
\hline & Intangible assets & $\begin{array}{l}\text { Intangibles cannot be easily defined and are therefore difficult to } \\
\text { assess, measure, and manage. Intangible assets can be classified into six } \\
\text { categories: (1) the 'having' capabilities, (2) the 'doing' capabilities, ( } 3 \text { ) } \\
\text { 'people dependency', (4) 'people independency', (5) protection by law, } \\
\text { and (6) no protection by law. }\end{array}$ & $\begin{array}{l}{[34]} \\
{[17]} \\
{[35]}\end{array}$ \\
\hline & $\begin{array}{l}\text { Analyse the } \\
\text { target's selling } \\
\text { motive }\end{array}$ & $\begin{array}{l}\text { When filtering the target enterprises, the acquiring party should analyse } \\
\text { every potential target enterprise's motive for merger or acquisition, in } \\
\text { order to determine the target enterprise and develop the pricing } \\
\text { strategy. }\end{array}$ & [36] \\
\hline & $\begin{array}{l}\text { Estimating } \\
\text { synergies }\end{array}$ & $\begin{array}{l}\text { Some synergies are achievable, and ignoring them may steer companies } \\
\text { away from smart acquisitions. A good approach is to use the due } \\
\text { diligence process to distinguish carefully between different kinds of } \\
\text { synergies, and then estimate both their potential value and the } \\
\text { probability that they can be realised. That assessment should also } \\
\text { include the speed with which the synergies can be achieved and the } \\
\text { investments it will take to get them. }\end{array}$ & $\begin{array}{l}{[37]} \\
{[25]} \\
{[26]}\end{array}$ \\
\hline & $\begin{array}{l}\text { Exposing and } \\
\text { managing risk }\end{array}$ & $\begin{array}{l}\text { Exposing major risks early in the due diligence process can help to } \\
\text { determine whether it is wise to continue with a deal. If it is determined } \\
\text { that the risk is acceptable, a risk-mitigation strategy should be } \\
\text { determined and implemented. }\end{array}$ & $\begin{array}{l}{[38]} \\
{[22]}\end{array}$ \\
\hline & $\begin{array}{l}\text { Establishing a } \\
\text { price }\end{array}$ & $\begin{array}{l}\text { Executives must be convinced not only that the potential deal value } \\
\text { justifies the significant investment being made, but also that the } \\
\text { business is truly capable of realising this value. The buyer should } \\
\text { demand a price that is commensurate with the level of integration risk } \\
\text { uncovered, and be willing to walk away if that price isn't met. }\end{array}$ & $\begin{array}{l}{[26]} \\
{[37]} \\
{[25]}\end{array}$ \\
\hline & $\begin{array}{l}\text { Produce a list of } \\
\text { likely revenue } \\
\text { enhancement } \\
\text { opportunities } \\
\text { (REO) }\end{array}$ & $\begin{array}{l}\text { Produce a list of REOs, and then prioritise how quickly and easily they } \\
\text { can be expected to be achieved. This provides a 'pipeline' or stream of } \\
\text { potential growth opportunities, some of which can begin immediately } \\
\text { after the acquisition, with others following later. }\end{array}$ & [27] \\
\hline
\end{tabular}




\begin{tabular}{|c|c|c|c|}
\hline CATEGORY & CONCEPT & DESCRIPTION & REFERENCES \\
\hline \multirow{4}{*}{ 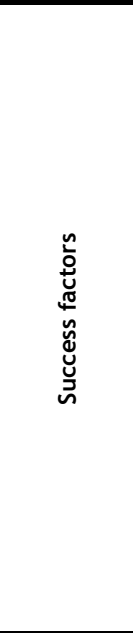 } & $\begin{array}{l}\text { Decide on } \\
\text { critical } \\
\text { success factors }\end{array}$ & $\begin{array}{l}\text { Critical success factors (CSFs) ground the vision and storyline into } \\
\text { tangible objectives and measurable milestones. They give shape to the } \\
\text { combination of functions, products, and services, and drive integration } \\
\text { decisions toward the creation of value. The CEO and top team must } \\
\text { define and ensure that these CSFs are kept at the top of priority lists } \\
\text { of managers if the combination is to succeed. They form the criteria } \\
\text { against which combination decisions and execution are evaluated. }\end{array}$ & [39] \\
\hline & $\begin{array}{l}\text { Targeted } \\
\text { debiased } \\
\text { approach }\end{array}$ & $\begin{array}{l}\text { The approach requires executives first to identify the cognitive } \\
\text { mechanisms at play during various decision-making steps, and then to } \\
\text { use a set of techniques to reduce bias at specific decision points, thus } \\
\text { leading to sounder judgements. }\end{array}$ & [25] \\
\hline & $\begin{array}{l}\text { Realisation of } \\
\text { the 'people } \\
\text { situation' in } \\
\text { the target } \\
\text { company }\end{array}$ & $\begin{array}{l}\text { To increase the chances of a long-term, financially successful MaA, } \\
\text { comprehensive due diligence must incorporate the realisation of the } \\
\text { 'people situation' in the target company. A thorough due diligence that } \\
\text { pays great attention to the target's workforce is aimed at discovering } \\
\text { both the company's people problems and its people strengths. }\end{array}$ & [24] \\
\hline & $\begin{array}{l}\text { Due diligence } \\
\text { activities } \\
\text { carried out by } \\
\text { successful } \\
\text { companies }\end{array}$ & $\begin{array}{l}\text { A clear, agreed vision shared by both parties. A detailed, prioritised } \\
\text { architecture for change. An architecture for the new company based } \\
\text { on the strengths of the two parties, and focused on maximising value. } \\
\text { A new leadership team chosen and communicated quickly. An explicit } \\
\text { plan to address cultural issues }\end{array}$ & [34] \\
\hline \multirow{8}{*}{ 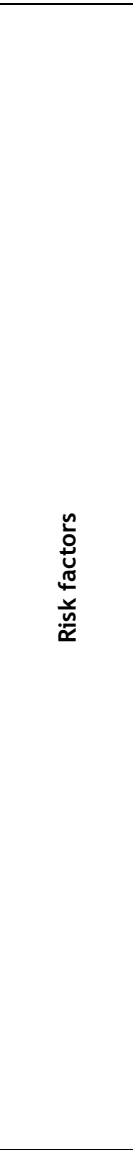 } & $\begin{array}{l}\text { Rushed due } \\
\text { diligence }\end{array}$ & $\begin{array}{l}\text { Due diligence is often hurried as excitement for the deal rises. The } \\
\text { due diligence process is then carried out inadequately, which may lead } \\
\text { to overestimations of revenue enhancement and cost savings, and } \\
\text { underestimation of the resource requirements and headaches involved } \\
\text { in integrating businesses. }\end{array}$ & [6] \\
\hline & $\begin{array}{l}\text { Ignoring } \\
\text { organisational, } \\
\text { HR, and } \\
\text { cultural issues }\end{array}$ & $\begin{array}{l}\text { Ignoring organisational culture differences, HR, or cultural issues may } \\
\text { have high long-term hidden costs. Either these people or cultural } \\
\text { issues never surface during the due diligence, or the acquirer } \\
\text { underestimates their importance and fails to recognise them as } \\
\text { warning signs of business problems that could sap value from the deal } \\
\text { and even threaten the success of the transaction. }\end{array}$ & $\begin{array}{l}{[2]} \\
{[24]} \\
{[25]}\end{array}$ \\
\hline & $\begin{array}{l}\text { Limiting the } \\
\text { due diligence } \\
\text { process }\end{array}$ & $\begin{array}{l}\text { Limiting the DD process to an evaluation of financial statements, } \\
\text { management, and physical assets leaves the acquisition process, and } \\
\text { more importantly, the acquirer, with serious vulnerabilities. It is } \\
\text { essential that DD goes beyond the obvious analyses and also includes a } \\
\text { detailed self-analysis and thorough review of the markets and } \\
\text { competitive environment of prospective acquisitions. }\end{array}$ & [23] \\
\hline & Verification & $\begin{array}{l}\text { Unless you are using a primary data source (such as official records } \\
\text { filed at a government institution), there is always going to be an issue } \\
\text { about whether the information is reliable or not. Once you start } \\
\text { moving out of your own jurisdiction, the likelihood is that you will be } \\
\text { less familiar with the data sources. }\end{array}$ & [33] \\
\hline & Timeliness & $\begin{array}{l}\text { The data can change very quickly. It is important to ensure, in the } \\
\text { checking process, that it is clear to the user of the data that the } \\
\text { checks undertaken in terms of financial performance and reputation } \\
\text { are only accurate at the point they were undertaken. Things can, and } \\
\text { do, change. Regular rechecking of client lists is part of the due } \\
\text { diligence process. }\end{array}$ & [33] \\
\hline & $\begin{array}{l}\text { Entrenched } \\
\text { business } \\
\text { processes }\end{array}$ & $\begin{array}{l}\text { Companies that acquire targets from firms in maturing industries must } \\
\text { 'untangle' the target's business processes from its parent company; in } \\
\text { most cases, the pieces being sold have entrenched processes and } \\
\text { cultures that are difficult to integrate into the buyer's organisation. }\end{array}$ & [10] \\
\hline & $\begin{array}{l}\text { The planning } \\
\text { fallacy }\end{array}$ & $\begin{array}{l}\text { People tend to underestimate the time, money, and other resources } \\
\text { needed to complete mergers and acquisitions. }\end{array}$ & [25] \\
\hline & $\begin{array}{l}\text { Confirmation } \\
\text { bias }\end{array}$ & $\begin{array}{l}\text { People tend to seek out information that validates an initial } \\
\text { hypothesis. The need to provide an acceptable initial bid often biases } \\
\text { all analyses upward. Instead of synergy estimates guiding the price, } \\
\text { the letter of intent often guides the synergy estimates. In effect, this } \\
\text { seeds the entire due diligence process with a biased estimate, even } \\
\text { before much information has been exchanged. }\end{array}$ & [25] \\
\hline
\end{tabular}

\section{TOWARDS THE DEVELOPMENT OF A CONCEPTUAL FRAMEWORK}

To assist in the development of a conceptual framework, the focus was on integrating and grouping together the concepts identified in phases 3 and 4. The framework provides a conceptualisation of the due diligence process.

Phase 5 of the CFA is covered in this section. Similar concepts were grouped together and combined. This decreased the overall number of concepts. The grouping and integration of concepts was assisted by the recognition of trends that emerged from the systematic literature review process. The process followed was to integrate, and group concepts were iterative. 
The concept categories were also organised into three main areas that laid the foundation of the conceptual framework. These areas, and the categories, can be seen in Table 9.

Table 9: Main areas for concept integration

\begin{tabular}{|c|c|c|}
\hline DUE DILIGENCE PROCESSES & DUE DILIGENCE PRINCIPLES & DUE DILIGENCE AREAS \\
\hline $\begin{array}{ll}\text { - } & \text { Steps } \\
\text { - } & \text { Planning } \\
\text { - } & \text { Tools }\end{array}$ & $\begin{array}{ll}\text { - } & \text { Best practices } \\
\text { - } & \text { Strategies } \\
\text { - } & \text { Success factors } \\
\text { - } & \text { Risk factors }\end{array}$ & $\begin{array}{ll}\text { - } & \text { Financial } \\
\text { - } & \text { Legal } \\
\text { - } & \text { Tax } \\
\text { - } & \text { Environmental } \\
\text { - } & \text { Operational } \\
\text { - } & \text { Market } \\
\text { - } & \text { Human resources } \\
\text { - } & \text { Cultural } \\
\text { - } & \text { Strategic } \\
\text { - } & \text { Marketing } \\
\text { - } & \text { Intellectual property } \\
\text { - } & \text { Technology } \\
\text { - } & \text { R\&D }\end{array}$ \\
\hline
\end{tabular}

\section{CONCLUSION AND FUTURE WORK}

Due diligence forms a critical component of the mergers and acquisitions process. Due diligence has become more than just a process to identify or review a candidate. Increasingly, due diligence teams are being asked to make calls on whether the targeted value of the deal can be realised, whether the projected timeframe is achievable, and whether all associated risks can be managed effectively [6]. It is evident that the due diligence process needs to be carefully controlled and monitored to ensure the maximum probability of success for the deal.

The systematic literature review carried out identified the core principles, processes, and concepts that make up the due diligence process. A comprehensive dataset of papers assisted in capturing these concepts, principles, and processes. The due diligence process was categorised according to the areas of due diligence, the process factors, and the concepts and principles. The principles, processes, and concepts that were captured were then analysed.

Jabareen's [11] CFA method was adopted. Phases 1 to 5 were covered by this paper. The basis of the conceptual framework was developed. The information and insight gained through this review will be used in developing the final conceptual framework by following phases 6 to 8 of the CFA. Phase 6 synthesises the concepts into a theoretical framework; phase 7 covers the validation of the framework; and phase 8 focuses on rethinking the framework by instituting changes recommended during the validation process.

This paper forms part of a larger research project for the due diligence stage of M\&As. Future work will be focused on the completion of the conceptual framework and its validation. A due diligence tool will then be developed, based on the conceptual framework.

\section{REFERENCES}

[1] Bruner, R. 2004. Applied mergers and acquisitions. New York: John Wiley \& Sons.

[2] Horwitz, F.M., Anderssen, K., Bezuidenhout, A., Cohen, S., Kirsten, F., Mosoeunyane, K., Smith, N., Thole, K., van Heerden, A., 2002. Due diligence neglected: Managing human resources and organisational culture in mergers and acquisitions, South African J. Bus. Manag., vol. 33, no. 1, pp. 1-10.

[3] Makri, M., Hitt, M.A. and Lane, P.J. 2010. Complementary technologies, knowledge relatedness, and invention outcomes in high technology mergers and acquisitions, Strateg. Manag. J., vol. 31, no. 6, pp. 602-628.

[4] Shimizu, K., Hitt, M.A., Vaidyanath, D. and Pisano, V. 2004. Theoretical foundations of cross-border mergers and acquisitions: A review of current research and recommendations for the future, Journal of International Management,. vol. 10, no. 3, pp. 307-353

[5] Hitt, M., Harrison, J. and Ireland, R. 2001. Mergers and acquisitions: A guide to creating value for stakeholders. New York: Oxford University Press.

[6] Marks, M.L. and Mirvis, P.H. 2015. "Managing the precombination phase of mergers and acquisitions, Adv. Mergers Acquisistions, vol. 14, no. January 2015, pp. 1-15. 
[7] Gomes, E., Angwin, D.N., Weber, Y. and Yedidia Tarba, S. 2013. Critical success factors through the mergers and acquisitions process: Revealing pre- and post-M\&A connections for improved performance, Thunderbird Int. Bus. Rev., vol. 55, no. 1, pp. 13-35.

[8] Galpin, T.J. and Herndon, M. 2007. The complete guide to mergers and acquisitions: Process tools to support M\&A integration at every level, Second edition. San Francisco, CA: John Wiley \& Sons.

[9] Delta Publishing Company. 2013. A practical guide to mergers, acquisitions and divestitures,. Los Alamitos: Delta Publishing Company

[10] Perry, J.S. and Herd, T.J. 2004. Reducing M\&A risk through improved due diligence, Strateg. Leadersh., vol. 32, no. 2, pp. 12-19.

[11] Jabareen, Y. 2009. Building a conceptual framework: Philosophy, definitions, and procedure, Int. J. Qual. Methods, vol. 8, no. 4, pp. 49-62.

[12] Bearman, M. and Dawson, P. 2013. Qualitative synthesis and systematic review in health professions education, Medical education, vol. 47, no. 3, pp. 252-260.

[13] Petticrew, M. and Roberts, H. 2006. Systematic reviews in the social sciences: A practical guide. Malden: Blackwell Publishing.

[14] Cooper, H.M. 2018. Scientific guidelines for conducting integrative research reviews, Review of Educational Research, Vol. 52, No. 2, pp. 291-302.

[15] Angwin, D. 2001. Mergers and acquisitions across European borders: National perspectives on preacquisition, due diligence and the use of professional advisers, J. World Bus., vol. 36, no. 1, pp. 32-57.

[16] Stachiwicz-Stanusch, A. 2009. Culture due diligence based on HP/Compaq merger case study, J. Intercult. Manag., vol. 1, pp. 64-81.

[17] Harvey, M.G. and Lusch, R.F. 1995. Expanding the nature and scope of due diligence. Puterbaugh Chair of American Free Enterprise Helen Robson Walton Chair of Marketing Strategy, vol. 9026, no. 94, pp. 521.

[18] Davidson, K. 1988. Tax-distorted mergers, J. Bus. Strateg., vol. 9, no. 5, pp. 63-64.

[19] Lemieux, P.O. and Banks, J.C. 2007. High tech M\&A: Strategic valuation, Manag. Decis., vol. 45, no. 9 , pp. 1412-1425.

[20] Maxwell, S. 1998. A merger manual, Civ. Eng., vol. 68, no. 2, pp. 73-75.

[21] Brancone-Capponi, E., Miller, M.L. and Cecconi, M. 2016. Environmental due diligence for commercial and residential real estate, Procedia Environmental Science, Engineering and Management, vol. 3, no. 1, pp. 15-21.

[22] Morrison, N.J., Kinley, G. and Ficery, K.L. 2008. Merger deal breakers: When operational due diligence exposes risk, J. Bus. Strategy, vol. 29, no. 3, pp. 23-28.

[23] Lebedow, A.L. 1999. Due diligence: More than a financial exercise, J. Bus. Strategy, vol. 20, no. 1, pp. 12-14.

[24] Latukha, M. and Panibratov, A. 2013. Is the role of HRM strategic in M\&A success? Exploring the involvement of HRM in a due diligence process, J. Gen. Manag., vol. 39, no. 1, pp. 27-54.

[25] Lovallo, D., Viguerie, P., Uhlaner, R. and Horn, J. 2007. Deals without delusions, Harvard Business Review, vol. 85, no. 12, pp. 92-99.

[26] Adolph, G., Gillies, S. and Krings, J. 2006. Strategic due diligence: A foundation for M\&A success, strategy business, pp. 13-50.

[27] Gould, B. 1998. Marketing due diligence ... where do customer and marketing details fit into pre-deal activity? The Antidote, vol. 3, no. 2, pp. 25-27,

[28] Kumar, S. and Hansted Blomqvist, K. 2004. Making brand equity a key factor in M\&A decision-making, Strateg. Leadersh., vol. 32, no. 2, pp. 20-27,

[29] Silverman, A.B. 2004. The importance of intellectual property and due diligence in mergers and acquisitions, Jounral of the Minerals, Metals and Materials Society, vol. 56, no. 3, p. 88.

[30] Breitzman, A. and Thomas, P. 2002. Using patent citation analysis to target/value M\&A candidates, Res. Technol. Manag., vol. 45, no. 5, p. 28,

[31] Melhelm, G., Ozog, H., Kenney, G., Groves, G. and Kalelkar, A. 2006. Safety guidelines for the merger and acquisition process, Process Saf. Prog., vol. 25, no. 4, pp. 326-33.

[32] Harvey, M. and Lusch, R.F. 1998. Beyond traditional due diligence for mergers and acquisitions in the 21st century, Rev. Bus., vol. 19, no. 3, p. 17.

[33] Ainsworth, M. 2007. Compleat compliance: Due diligence on companies and individuals, Bus. Inf. Rev., vol. 24, no. 4, pp. 245-252.

[34] McGrady, S. 2005. Extending due diligence to improve mergers and acquisitions, Bank Account. Financ., vol. 18, no. 4, pp. 17-23.

[35] Denison, D.R. and Ko, I. 2016. Cultural due diligence in mergers and acquisitions, Advances in Mergers and Acquisitions, vol. 15, pp. 53-72.

[36] Song, X.L., Zhang, Q.S., Chu, Y.H. and Song, E.Z. 2009. A study on financial strategy for determining the target enterprise of merger and acquisition, 2009 IEEE/INFORMS Int. Conf. Serv. Oper. Logist. Informatics, SOLI 2009, pp. 477-480.

[37] Cullinan, G., Le Roux, J.M. and Weddigen, R.M. 2004. When to walk away from a deal, Harv. Bus. Rev., vol. 82 , no. 4 , p. 96-104.

[38] Knecht, F. and Calenbuhr, V. 2007. Using capital transaction due diligence to demonstrate CSR assessment in practice, Corp. Gov. Int. J. Bus. Soc., vol. 7, no. 4, pp. 423-433.

[39] Marks, M.L. and Mirvis, P.H. 2001. Making mergers and acquisitions work: Strategic and psychological preparation., Acad. Manag. Exec., vol. 15, no. 2, pp. 80-92. 
[40] Bradley, C. 2016. Executing on integration: The key to success in mergers and acquisitions, Nurs. Adm. Q., vol. 40, no. 4, pp. 316-320.

[41] Einhorn, S. 2018. Loose lips can sink ships, Adhesives Age, vol. 28, no. 1, pp. 7-35.

[42] Endert, V. and Mammen, A. 2015. Improving the acquisition profit of cross border transactions by adjusting the tax due diligence process - A theoretical model based on a German target, Period. Polytech. Soc. Manag. Sci., vol. 23, no. 1, pp. 41-50.

[43] Garzella, S. and Fiorentino, R. 2014. A synergy measurement model to support the pre-deal decision making in mergers and acquisitions, Manag. Decis., vol. 52, no. 6, pp. 1194-1216.

[44] MacLean, R. 2000. Doing the Deal Part 3: ENHANCED Environmental Due Diligence, Air and Waste Management Association's Magazine for Environmental Managers,

[45] Sacek, A. 2016. Critical factors of pre-acquisition due diligence in cross-border acquisitions, Contemporary Issues in Finance: Current Challenges Facing Europe, Emerald Group Publishing Limited.

[46] Savovic, S. and Pokrajcic, D. 2013. Due diligence as a key success factor of mergers and acquisitions, ACTUAL Probl. Econ., vol. 6, no. 144, pp. 424-434.

[47] Traves, L.S. 2002. Double due diligence: Incorporating strategic environmental assessments for industrial mergers and acquisitions, Environmental Practice, vol. 4, no. 4, pp. 197-209.

[48] Tsao, C. 2009. The fuzzy MCDM algorithms for the M\&A due diligence, Syst. Cybern. INFORMATICS, vol. 6, no. 2, pp. 17-22.

[49] Kroll Advisory Solutions. 2012. Private equity into high-risk markets,

[50] GrantThornton. 2004. Due diligence review: M\&A behind the scenes,

[51] Harding, D. and Rouse, T. 2007. Human due diligence, Harv. Bus. Rev., vol. 85, no. 7-8, p. 185.

[52] Hindle, K. 1994. Dynamic due diligence: An enterpreneurial business planning method for theory, case application and general implications, Swinburne Rev. Entrep., vol. 2, no. 2, pp. 61-77.

[53] Wangerin, D.D. 2010. M\&A due diligence and its consequences for post-acquisition financial statements, Working paper, Michigan State University pp. 1-50. 


\section{APPENDIX A}

\begin{tabular}{|c|c|c|}
\hline Number & Title of paper & Reference \\
\hline 1 & Compleat compliance: Due diligence on companies and individuals & [33] \\
\hline 2 & Executing on Integration: The Key to Success in Mergers and Acquisitions & [40] \\
\hline 3 & Environmental due diligence for commercial and residential real estate & [21] \\
\hline 4 & Using patent citation analysis to target-value M\&A candidates & [30] \\
\hline 5 & When to Walk Away from a Deal & [37] \\
\hline 6 & Cultural due diligence in mergers and acquisitions & [35] \\
\hline 7 & Loose lips can sink ships & [41] \\
\hline 8 & $\begin{array}{l}\text { Improving the acquisition profit of cross border transactions by adjusting the tax } \\
\text { due diligence process }-\mathrm{A} \text { theoretical model based on a German target }\end{array}$ & [42] \\
\hline 9 & $\begin{array}{l}\text { A synergy measurement model to support the pre-deal decision making in mergers } \\
\text { and acquisitions }\end{array}$ & [43] \\
\hline 10 & Using capital transaction due diligence to demonstrate CSR assessment in practice & {$[38]$} \\
\hline 11 & Making brand equity a key factor in M\&A decision-making & [28] \\
\hline 12 & $\begin{array}{l}\text { Is the role of HRM strategic in M\&A success? Exploring the involvement of HRM in a } \\
\text { due diligence process }\end{array}$ & [24] \\
\hline 13 & M\&A: Due Diligence: More Than a Financial Exercise & [23] \\
\hline 14 & High tech M\&A - Strategic valuation & [19] \\
\hline 15 & Deals without delusions & [25] \\
\hline 16 & Doing the Deal Part 3: Enhanced Environmental Due Diligence & [44] \\
\hline 17 & Merger manual & [20] \\
\hline 18 & Safety guidelines for the merger and acquisition process & [31] \\
\hline 19 & Merger deal breakers: When operational due diligence exposes risk & [22] \\
\hline 20 & Reducing M\&A risk through improved due diligence & [10] \\
\hline 21 & Critical factors of pre-acquisition due diligence in cross-border acquisitions & [45] \\
\hline 22 & $\begin{array}{l}\text { A study on financial strategy for determining the target enterprise of merger and } \\
\text { acquisition }\end{array}$ & [36] \\
\hline 23 & Due diligence as a key success factor of mergers and acquisitions & [46] \\
\hline 24 & The importance of intellectual property due diligence in mergers and acquisitions & [29] \\
\hline 25 & $\begin{array}{l}\text { Double due diligence: Incorporating strategic environmental management in } \\
\text { environmental assessments for industrial mergers and acquisitions }\end{array}$ & [47] \\
\hline 26 & $\begin{array}{l}\text { Applying a fuzzy multiple criteria decision-making approach to the M\&A due } \\
\text { diligence }\end{array}$ & [48] \\
\hline 27 & Strategic Due Diligence: A Foundation for M\&A Success & [26] \\
\hline 28 & $\begin{array}{l}\text { Mergers and Acquisitions across European Borders: National Perspectives on Pre- } \\
\text { acquisition Due Diligence and the Use of Professional Advisers }\end{array}$ & [15] \\
\hline 29 & Private equity into high-risk markets - The need for a new due diligence approach & [49] \\
\hline 30 & Due Diligence Review: M\&A Behind the Scenes & {$[50]$} \\
\hline 31 & $\begin{array}{l}\text { Marketing due diligence ... where do customer and marketing details fit into pre- } \\
\text { deal activity? }\end{array}$ & [27] \\
\hline 32 & Human Due Diligence & [51] \\
\hline 33 & Expanding the nature and scope of due diligence & [17] \\
\hline 34 & Beyond traditional due diligence for mergers and acquisitions in the 21st century & [32] \\
\hline 35 & $\begin{array}{l}\text { Dynamic due diligence an entrepreneurial business planning method for evaluating } \\
\text { mergers and acquisitions }\end{array}$ & [52] \\
\hline 36 & $\begin{array}{l}\text { Due diligence neglected: managing human resources and organisational culture in } \\
\text { mergers and acquisitions }\end{array}$ & [2] \\
\hline 37 & Managing the pre-combination phase of mergers and acquisitions & [6] \\
\hline 38 & Extending Due Diligence to Improve Mergers and Acquisitions & [34] \\
\hline 39 & M\&A Due Diligence and its Consequences for Post-Acquisition Financial Statements & [53] \\
\hline
\end{tabular}

